\title{
HEPATOTOXICITY INDUCED BY MONOSODIUM GLUTAMATE (MSG) IN RATS AND THE POSSIBLE HEPATOPROTECTIVE ROLE OF N-ACETYLCYSTEINE
}

\author{
Mohammed F. Abbas and Ahmed Hefnawy Abbas. \\ Department of Forensic Medicine and Clinical Toxicology- Faculty of Medicine - Minia \\ University Egypt
}

\begin{abstract}
Mono sodium glutamate (MSG) is commonly marketed as a flavor enhancer and is used as a food additive. The present study was carried out to study the effect of MSG at two oral low doses of 0.6 and $1.6 \mathrm{mg} / \mathrm{g}$ body weight on liver functions during feeding period ( 2 weeks) in albino rats and to investigate the effect of oral administration of $\mathrm{N}$-acetylcysteine on hepatotoxicity induced to rats by (MSG). six groups as follows; group 1: control; group 2: received oral $0.6 \mathrm{mg} / \mathrm{g}$ body weight of MSG, group 3: received oral $1.6 \mathrm{mg} / \mathrm{g}$ b. wt of $\mathrm{MSG}$, group 4: received oral $\mathrm{N}$ acetylcysteine in a dose of $200 \mathrm{mg} / \mathrm{kg} \mathrm{b}$. wt. group 5: received oral $0.6 \mathrm{mg} / \mathrm{g} \mathrm{b}$. wt of MSG plus $200 \mathrm{mg} / \mathrm{g}$ body weight $\mathrm{N}$-acetylcysteine and group 6: received oral gavage of $1.6 \mathrm{mg} / \mathrm{g} \mathrm{b}$. wt of MSG plus $200 \mathrm{mg} / \mathrm{g} \mathrm{b}$.wt N-acetylcysteine on a daily basis. The rats were sacrificed on the fifteenth day of the experiment. Measuring serum levels of aspartate aminotransferase (AST), alanine aminotransferase (ALT) and alkaline phosphatase (ALP); albumin, total protein, total bilirubin, lactate dehydrogenase (LDH) enzyme and glutathione reductase (GR) was done. Histopathological examination of liver was performed. Many biochemical changes of statistically significance change were obvious. Inflammatory cells infiltrated, apoptotic bodies, necro-inflammatory foci were observed. The results suggested that $\mathrm{N}$-acetylcysteine had potent hepatoprotective and antioxidant effects in MSG - hepatotoxic rats.
\end{abstract}

KEYWORDS: MSG, Lactate dehydrogenase (LDH); Glutathione reductase (GR); Histopathology; Liver; N-acetylcysteine.

\section{INTRODUCTION}

Monosodium Glutamate (MSG) is sodium salt of non-essential naturally occurring L-form of glutamic acid. It is a white crystalline powder in its pure form (Furst \& Stehle, 2004). It contains $78 \%$ of glutamic acid, $22 \%$ of sodium and water (Samuels, 1999).

Ajinomoto, Vestine, Ac,cent tasting powder (Beyreuther et al., 2007), A-one and vedan, , are commonly marketed trade names of MSG (Obaseiki-Ebor et al., 2003).

As a flavor enhancer, MSG is commonly marketed and is used as a food additive especially in Asian dishes and West African (Farombi \& Onyema, 2006).

On food labels, MSG is described and listed as a "Flavouring" or "Hydrolysed vegetable protein". It positively influences appetite and induces weight gain through its stimulation of the Orosensory receptors and improving the palatability of meals (Moore, 1999).

Unlike other four basic flavor sensations, the flavor sensation of MSG is often described as "meaty" and has been given the name "umami (Berkes, \& Wossner, 2003). 
Glutamate, when bound to proteins, is tasteless. When free glutamate dissociates from proteins; during the processes of fermentation, ripening and cooking, the sweet umami taste and flavor becomes perceptible. Large quantity of glutamate are present in cheese, mushrooms and tomatoes and thus used to enrich the flavor and taste of foods (Oyetunji, 2013).

Commercially MSG is produced by molasses fermentation and it is used in home cooking, restaurants and for industrial food production (Farombi $\&$ Onyema, 2006).

It (MSG) is excitotoxin food additive which can generate numerous amounts of free radicals that can destroy neurons, other tissues and organs (liver and red blood cells). A 4hydroxynonenal is produced during lipid peroxidation which inhibits glutamate transporter, with glutamate accumulation in the brain (Freeman, 2006).

The natural glutamic acid in food is not harmful, while the synthetic free glutamic acid is toxic (Geha et al., 1998). Although MSG has been classified by FDA that's generally recognized as safe, its use remains controversy (Ortiz et al., 2006).

One of the possible adverse effects of MSG is Chinese restaurant syndrome which is characterized by headache, flushing, numbness, muscle tightness, generalized weakness and bronchoconstriction in asthmatics (Cortese \& Phan, 2005). In high doses, MSG can produce neuroendocrine abnormalities, neuronal degeneration (Moreno et al., 2005) and oxidative damage in different organs (Farombi \& Onyema, 2006), (Pavlovic et al., 2007). Also, retinal degeneration, stroke, epilepsy, brain trauma, neuropathic pain, schizophrenia anxiety, depression, Parkinson's disease, Alzheimer's disease, Huntington's disease and amyotrophic lateral sclerosis are reported (Samuels, 1999). Others are reduction of the reproductive ability in female and male mice (Mozes \& Sefcikova, 2000).

$\mathrm{N}$-acetylcysteine (NAC) is a wellknown thiolic antioxidant. It can act through several mechanisms against cellular degeneration (Euteum et al., 2014).

Considering the discrepancies in the literature and the growing safety concern for the use of MSG, there is need for further studies on this food additive. So, the current study was conducted to investigate if MSG intake at a low dose could be toxic on selected hepatocellular functions of male albino rats and to evaluate the role of NAC in MSG hepatotoxicity.

\section{MATERIALS \& METHODS}

\section{Animals:}

Thirty six adult male albino rats with average weight of 200-220 g were obtained from Minia University Animal Care Center.

\section{Chemicals:}

MSG was purchased from Morgan Company for Chemical Industry (Tenth of Ramadan City- Egypt). Nacetylcysteine was obtained from Sigma-Aldrich Chemicals Co. (St. Louis, MO, USA). All chemical reagents were of analytical grades and purchased from Sigma Chemical Co. (St. Louis, MO, USA).

\section{Experimental protocol}

Thirty six adult male albino rats of weighting 200-220 g were housed in plastic cages (six rats/cage) with wood shavings. Rats were kept in a 
temperature-controlled room at $24 \pm 1^{\circ} \mathrm{C}, 50 \%$ humidity and $12 \mathrm{hrs} / 12$ hrs. light/ dark cycle. Rats were adapted to the environment for one week prior to the start of experiment. Animals were fed on rat pellets and water was provided ad libitum during experimental period (14 days). The rats were randomly distributed into six equal groups of six rats each as follows:

Group 1 (Control): Rats were fed on the basal diet and water was provided ad libitum.

Group 2: Rats were fed on the basal diet and received oral gavage of $0.6 \mathrm{mg} / \mathrm{g}$ body weight of MSG on a daily basis, to induce hepatotoxicity.

Group 3: Rats were fed on the basal diet and received oral gavage of $1.6 \mathrm{mg} / \mathrm{g}$ body weight of MSG on a daily basis, to induce hepatotoxicity.

Group 4: Rats were fed on the basal diet and received oral gavage of NAC in a dose of $200 \mathrm{mg} / \mathrm{kg}$ body weight.

Group 5: Rats were fed on the basal diet and received oral gavage of $0.6 \mathrm{mg} / \mathrm{g}$ body weight of MSG plus 200 $\mathrm{mg} / \mathrm{g}$ body weight NAC on a daily basis;

Group 6: Rats were fed on the basal diet and received oral gavage of $1.6 \mathrm{mg} / \mathrm{g}$ body weight of MSG plus 200 $\mathrm{mg} / \mathrm{g}$ body weight NAC on a daily basis;

The rats were sacrificed on the fifteenth day of the experiment. The choice of MSG doses was based on previous reported studies (Manivasagan and Subramanian, 2004).

\section{Blood Collection and Separation}

At the end of the experimental period, the rats were fasted overnight. On the morning of the next day the rats were anesthetized by general volatile anesthesia using ether. After induction of mild anesthesia (avoidance of strong deep anaesthesia to maintain regular and strong heart beats to get enough amount of blood), the rat was rapidly pulled out and blood was collected. The animals were then fixed on a dissecting plate, dissected under complete aseptic conditions. Blood samples were withdrawn by capillary microtubes (Micro Hematocrite Capillaries, Mucaps) from the retro-orbital plexuses of veins in inner canthus of the eye into plain tube with gel. The blood samples were centrifuged at $3000 \mathrm{rpm}$ for 15 minutes. Serum samples were separated and frozen at $-80{ }^{\circ} \mathrm{C}$ until used for the biochemical analysis. After decapitation of the rats, the liver was removed by careful dissection and blotted free of adhering blood immediately after sacrificing the rats for histological study.

\section{Serum Biochemical Analysis}

Biochemical measurement of serum levels of liver enzymes; aspartate aminotransferase (AST), alanine aminotransferase (ALT) and alkaline phosphatase (ALP); albumin, total protein, total bilirubin, lactate dehydrogenase (LDH) enzyme was performed using spectrophotometric techniques (Dimension Vista system, Siemens Healthcare Diagnostics Inc., USA).

Estimation of Serum Oxidative Stress Markers (Glutathione Reductase) (GR):

Tests of antioxidant enzyme were performed using enzyme-linked immunosorbent assay (ELISA) technique (Microplate reader, Biotech, USA). Glutathione reductase enzyme activity was determined according to the method described by Carlberg and 
Mannervik, (1985).

\section{Histopathological study}

All animals were sacrificed on the day $15^{\text {th }}$ of the experiment and the liver from the six groups were rapidly excised, cut into small pieces and dropped in formalin in which they were kept for appropriate time. After fixation, they were subjected to the usual procedure for paraffin embedding. Sections were cut at the thickness of 5 microns and stained with Haematoxyline-Eosin and Periodic acid Schiff reaction (PAS) and then tissue sections were investigated using light microscope according to Drury and Wallington, (1980).

\section{Statistical Analysis}

The collected data was organized and tabulated. Data were expressed as means \pm standard deviation (SD). Statistical analysis of variance between mean values of different groups was performed using Kruskal-Wallis test followed by the Mann-Whitney test to determine the variance between all rat groups. Differences were considered significant at $\mathrm{P}<0.05$. Statistical analysis was done using computerized SPSS program (Statistical Package for the Social Sciences, version 16).

\section{RESULTS}

\section{- Biochemical changes}

Effect of N-acetylcysteine on serum liver enzymes AST, ALT and ALP in hepatotoxic rats induced by MSG is recorded in Table 1 and is shown in Figs.1, 2 and 3.

It was obvious from table 1 and figs. 1, 2 and 3 of group 2 rats (orally fed $0.6 \mathrm{mg} / \mathrm{g}$ b.wt. MSG) showed significant statistical $(\mathrm{p}<0.05)$ increase in serum levels of AST and ALT as compared to the control group, meanwhile, serum level of ALP enzyme showed no significant change when compared to the control group. Concerning group 3 rats (orally given $1.6 \mathrm{mg} / \mathrm{g}$ b.wt MSG), significant statistical $\quad(p<0.05)$ increase was elicited in serum levels of AST, ALT and ALP enzymes in comparison to the control group. There were no significant changes in serum levels of AST, ALT and ALP enzymes in group 4 rats (orally given $200 \mathrm{mg} / \mathrm{g}$ b.wt. NAC) when compared to the control group. Groups 5 and 6 rats (orally treated with $0.6 \mathrm{mg} / \mathrm{g}$ and $1.6 \mathrm{mg} / \mathrm{g}$ b.wt. MSG respectively and coadministred with $200 \mathrm{mg} / \mathrm{g}$ b.wt. NAC) afforded significant $(\mathrm{p}<0.05)$ statistical decreased in levels of serum AST and ALT enzymes as compared to groups 2 and 3. As regards serum ALP enzyme levels, there were no significant change in groups 5 and 6 when compared to groups 2 and 3 .

Effect of $\mathrm{N}$-acetylcysteine on serum LDH, ALB, TP, and TBIL in hepatotoxic rats induced by MSG is recorded in Table 2 and shown in Figs. 4,5,6,7.

As seen in table 2 and figs. 4, 5, 6 and 7 , the oral administration of MSG at dose of $0.6 \mathrm{mg} / \mathrm{g} \mathrm{b}$.wt. to rats after feeding period of 2 weeks (group 2) showed no significant change in serum LDH as compared to the control group. There were significant $(\mathrm{p}<0.05)$ statistical decreases in serum ALB and TP levels of group 2 when compared to the control group. Serum TBIL showed a significant statistical $\quad(p<0.05)$ increase in group 2 when compared to the control group. The results revealed that oral administration of MSG at dose $1.6 \mathrm{mg} / \mathrm{g} \mathrm{b}$. wt. to rats for feeding period of 2 weeks (group 3) showed significant statistical $(\mathrm{p}<0.05)$ increase in serum LDH and TBIL in comparison 
with the control group. Moreover, there were significant statistical decrease $(p<0.05)$ in serum levels of ALB and TP when compared to the control group. No significant changes were elicited in serum levels of LDH, ALB, TP and TBIL in rats orally given 200 $\mathrm{mg} / \mathrm{g}$ b.wt. NAC, when compared to the control group. Administration of $0.6 \mathrm{mg} / \mathrm{g}$ b. wt. of MSG plus $200 \mathrm{mg} / \mathrm{g}$ b. wt. NAC (group 5) showed no significant change in serum $\mathrm{LDH}$ compared to the group 2. Conversely, there were significant $(p<0.05)$ increases in serum ALB and TP in group 5 when compared to group 2 . Serum TBIL showed a significant $(p<0.05)$ decrease in rats of group 5 when compared to group 2. Regarding serum ALB and TP levels, there were no significant change in group 6 (rats orally given $1.6 \mathrm{mg} / \mathrm{g} \mathrm{b}$. wt. of MSG plus $200 \mathrm{mg} / \mathrm{g}$ b. wt. NAC compared to group 3. Meanwhile, there were significant $(\mathrm{p}<0.05)$ decreases in serum LDH and TBIL in rats of group 6 when compared to group 3.

The effect of $\mathbf{N}$-acetylcysteine on serum GR in hepatotoxic rats induced by MSG is recorded in table 3 and shown in fig. 8.

Significant statistical decreases $(\mathrm{p}<0.05)$ in serum GR enzyme in groups 2 and 3 (rats orally administered of MSG at two dosage 0.6 and $1.6 \mathrm{mg} / \mathrm{g}$ b wt.), after feeding period of 2 weeks, in comparison with the control group. No significant statistical changes were observed in serum GR enzyme in rats orally given NAC in a dose of 200 $\mathrm{mg} / \mathrm{kg}$ b.wt. when compared to the control group. It was clear that, there were significant statistical $(\mathrm{p}<0.05)$ increase in serum GR enzyme levels in groups 5 and 6 as compared to groups 2 and 3 rats.

\section{- Histopathological changes}

Light microscopic examination of the liver section of group 1 rats (control) and group 4 rats (orally given $200 \mathrm{mg} / \mathrm{gm}$ b.wt. NAC) showed normal liver architecture of hepatic lobule without any histopathological changes. Irregular interconnecting sheets radiated outwards from the central vein (fig. 9). In rats of group 2 congested central vein with infiltration of inflammatory cells through the hepatic lobules and within portal tract were elicited. Apoptotic bodies (the hepatic cells are swollen with degeneration of the nuclei with prominent nucleoli) was also elicited (fig. 10). Necroinflammatory foci were revealed within the hepatic lobule in group 3 rats. Necrosis of hepatic cells with infiltration of inflammatory cells through the hepatic lobules and portal tract (portal triaditis) as shown in (fig. 11). Administration of NAC to $0.6 \mathrm{mg} / \mathrm{gm} \mathrm{MSG}$ in Group 5 rats was associated with mild inflammatory cells infiltration through the hepatic lobules with few apoptotic bodies and absence of central vein congestion as shown in (fig. 12). Meanwhile, administration of NAC to $1.6 \mathrm{mg} / \mathrm{gm} \mathrm{MSG}$ in group 6 rats showed infiltration of inflammatory cells through the hepatic lobules and within portal tract, central vein congestion and some apoptotic bodies with absence of necrotic areas as shown in (fig.13). 
Table (1): Mean values of serum (AST), (ALT) and (ALP) enzymes of different groups of rats after using two doses of monosodium glutamate $(0.6 \mathrm{mg} / \mathrm{g} \& 1.6$ $\mathrm{mg} / \mathrm{g}$ rat) and $\mathrm{N}$-acetylcysteine for 2 weeks expressed as (mean $\pm \mathrm{SD}$ ).

\begin{tabular}{|c|c|c|c|}
\hline Groups & $\begin{array}{l}\text { AST } \\
\text { (U/I) }\end{array}$ & $\begin{array}{l}\text { ALT } \\
\text { (U/I) }\end{array}$ & $\begin{array}{l}\text { ALP } \\
\text { (U/I) }\end{array}$ \\
\hline 1. Control & $161.57 \pm 6.90^{\mathrm{d}}$ & $55.40 \pm 5.01^{\mathrm{c}}$ & $153.50 \pm 6.95^{\mathrm{b}}$ \\
\hline 2. MSG1 (0.6 mg/g) & $192.00 \pm 2.00^{\mathrm{b}}$ & $64.00 \pm 3.10^{\mathrm{b}}$ & $170.50 \pm 1.51^{\mathrm{a}, \mathrm{b}}$ \\
\hline 3. MSG2 (1.6 mg/g) & $213.50 \pm 0.60^{\mathrm{a}}$ & $73.33 \pm 1.53^{\mathrm{a}}$ & $198.50 \pm 2.36^{\mathrm{a}}$ \\
\hline 4. NAC & $164.00 \pm 5.90^{\mathrm{d}}$ & $55.00 \pm 3.02^{\mathrm{c}}$ & $151.66 \pm 4.94^{\mathrm{b}}$ \\
\hline 5. NAC+ MSG1 (0.6 mg/g) & $169.31 \pm 8.30^{\mathrm{c}, \mathrm{d}}$ & $58.00 \pm 1.10^{\mathrm{c}}$ & $164.50 \pm 2.43^{\mathrm{a}, \mathrm{b}}$ \\
\hline 6. NAC + MSG2 $(1.6 \mathrm{mg} / \mathrm{g})$ & $177.40 \pm 5.50^{\mathrm{c}}$ & $64.00 \pm 1.00^{\mathrm{b}}$ & $176.00 \pm 14.72^{\mathrm{a}, \mathrm{b}}$ \\
\hline
\end{tabular}

(AST)Aspartate aminotransferase, (ALT) alanine aminotransferase, (ALP) alkaline phosphatase enzymes, U/l=unit /liter- Control: fed on control diet, MSG1: received $0.6 \mathrm{mg} / \mathrm{g}$ b.wt. MSG, MSG2: received $1.6 \mathrm{mg} / \mathrm{g}$ b.wt. MSG, NAC: received $200 \mathrm{mg} / \mathrm{kg}$ b.wt. NAC, NAC+ MSG1: administrated of NAC (200 mg $/ \mathrm{kg}$ b.wt.)+ MSG (0.6 mg/g b.wt.), NAC + MSG2: administrated of NAC (200 $\mathrm{mg} / \mathrm{kg}$ b.wt.)+ MSG (1.6 mg/g b.wt.). Values with different superscript letters within a column are significantly different at $\mathrm{p}<0.05$, while those with similar or partially similar are non-significant. $\mathrm{P}$ value calculated using Kruskal-Wallis test followed by the Mann-Whitney test.

Table (2): Mean values of serum LDH, ALB, TP and total bilirubin TBIL of different groups of rats after using two doses of monosodium glutamate $(0.6 \mathrm{mg} / \mathrm{g}$ $\& 1.6 \mathrm{mg} / \mathrm{g} \mathrm{rat}$ ) and $\mathrm{N}$-acetylcysteine for 2 weeks expressed as (mean $\pm \mathrm{SD}$ ).

\begin{tabular}{|l|c|c|c|c|}
\hline \multicolumn{1}{|c|}{ Groups } & $\begin{array}{c}\text { LDH } \\
(\mathbf{U} / \mathbf{l})\end{array}$ & $\begin{array}{c}\text { ALB } \\
(\mathbf{g} / \mathbf{l})\end{array}$ & $\begin{array}{c}\text { TP } \\
(\mathbf{g} / \mathbf{l})\end{array}$ & $\begin{array}{c}\text { TBIL } \\
(\boldsymbol{\mu m o l} / \mathbf{l})\end{array}$ \\
\hline 1. Control & $2649.65 \pm 12.02^{\mathrm{c}}$ & $12.50 \pm 0.50^{\mathrm{a}}$ & $73.00 \pm 5.00^{\mathrm{a}}$ & $1.17 \pm 0.02^{\mathrm{c}}$ \\
\hline 2. MSG1 & $2812.09 \pm 29.66^{\mathrm{c}}$ & $10.86 \pm 0.32^{\mathrm{b}}$ & $64.50 \pm 0.50^{\mathrm{b}}$ & $2.34 \pm 0.11^{\mathrm{a}}$ \\
\hline 3. MSG2 & $3708.01 \pm 46.19^{\mathrm{a}}$ & $10.20 \pm 0.26^{\mathrm{b}}$ & $61.50 \pm 0.50^{\mathrm{b}}$ & $2.51 \pm 0.05^{\mathrm{a}}$ \\
\hline 4. NAC $(\mathbf{2 0 0} \mathbf{~ m g / g )}$ & $2667.09 \pm 27.59^{\mathrm{c}}$ & $12.66 \pm 0.57^{\mathrm{a}}$ & $73.00 \pm 3.00^{\mathrm{a}}$ & $1.18 \pm 0.02^{\mathrm{c}}$ \\
\hline 5. NAC+ MSG1 & $2770.65 \pm 37.90^{\mathrm{c}}$ & $11.86 \pm 0.32^{\mathrm{a}}$ & $71.00 \pm 1.00^{\mathrm{a}}$ & $2.01 \pm 0.05^{\mathrm{b}}$ \\
\hline 6. NAC + MSG2 & $3413.32 \pm 67.96^{\mathrm{b}}$ & $10.86 \pm 0.32^{\mathrm{b}}$ & $67.33 \pm 1.15^{\mathrm{a}, \mathrm{b}}$ & $2.17 \pm 0.2^{\mathrm{b}}$ \\
\hline
\end{tabular}

(LDH) serum lactate dehydrogenase, (ALB) albumin, (TP) total protein and (TBIL) total bilirubin. Group distribution is the same as above in table (1). Values with different superscript letters within a column are significantly different at $\mathrm{p}<0.05$, while those with similar or partially similar are nonsignificant. P value calculated using Kruskal-Wallis test followed by the Mann-Whitney test.

Table (3): Mean values of serum antioxidant enzyme Glutathione reductase (GR) of different groups of rats after using two doses of monosodium glutamate $(0.6 \mathrm{mg} / \mathrm{g}$ $\& 1.6 \mathrm{mg} / \mathrm{g}$ rat) and $\mathrm{N}$-acetylcysteine for 2 weeks expressed as (mean $\pm \mathrm{SD}$ ).

\begin{tabular}{|l|c|}
\hline \multicolumn{1}{|c|}{ Groups } & GR $(\mathrm{U} / \mathrm{ml})$ \\
\hline Control & $79.86 \pm 1.14^{\mathrm{a}}$ \\
\hline 1. MSG1 $(\mathbf{0 . 6} \mathbf{~ m g / g})$ & $62.47 \pm 1.40^{\mathrm{c}}$ \\
\hline 2. MSG2 (1.6 mg/g) & $57.66 \pm 0.24^{\mathrm{d}}$ \\
\hline 3. NAC & $81.04 \pm 1.01^{\mathrm{a}}$ \\
\hline 4. NAC+ MSG1 (0.6 mg/g) & $72.97 \pm 1.11^{\mathrm{b}}$ \\
\hline 5. NAC + MSG2 (1.6 mg/g) & $67.11 \pm 0.92^{\mathrm{b}}$ \\
\hline
\end{tabular}

Group distribution is the same as above in table (1). Values with different superscript letters within a column are significantly different at $p<0.05$, while those with similar or partially similar are non-significant. P value calculated using Kruskal-Wallis test followed by the Mann-Whitney test. 


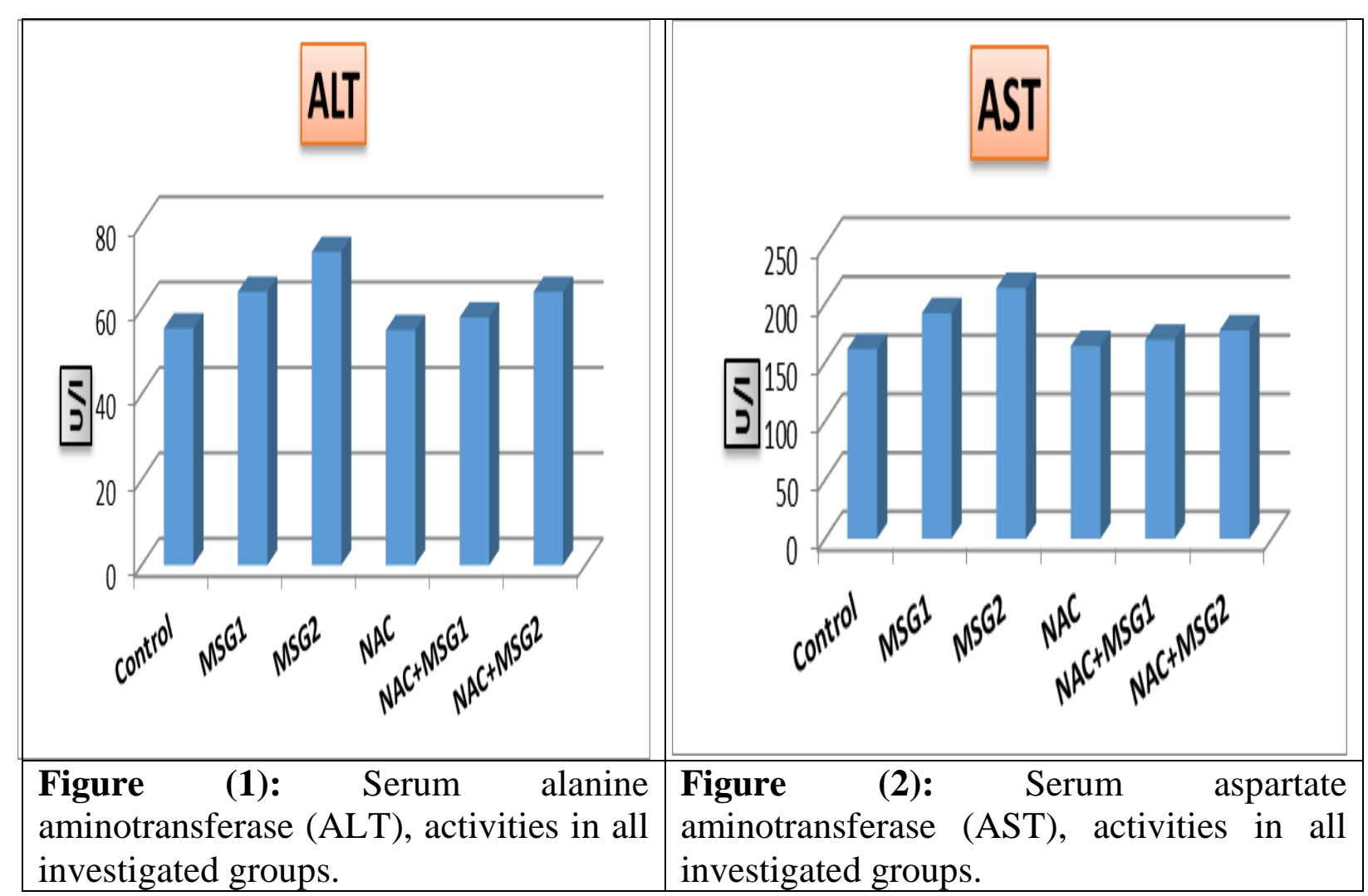

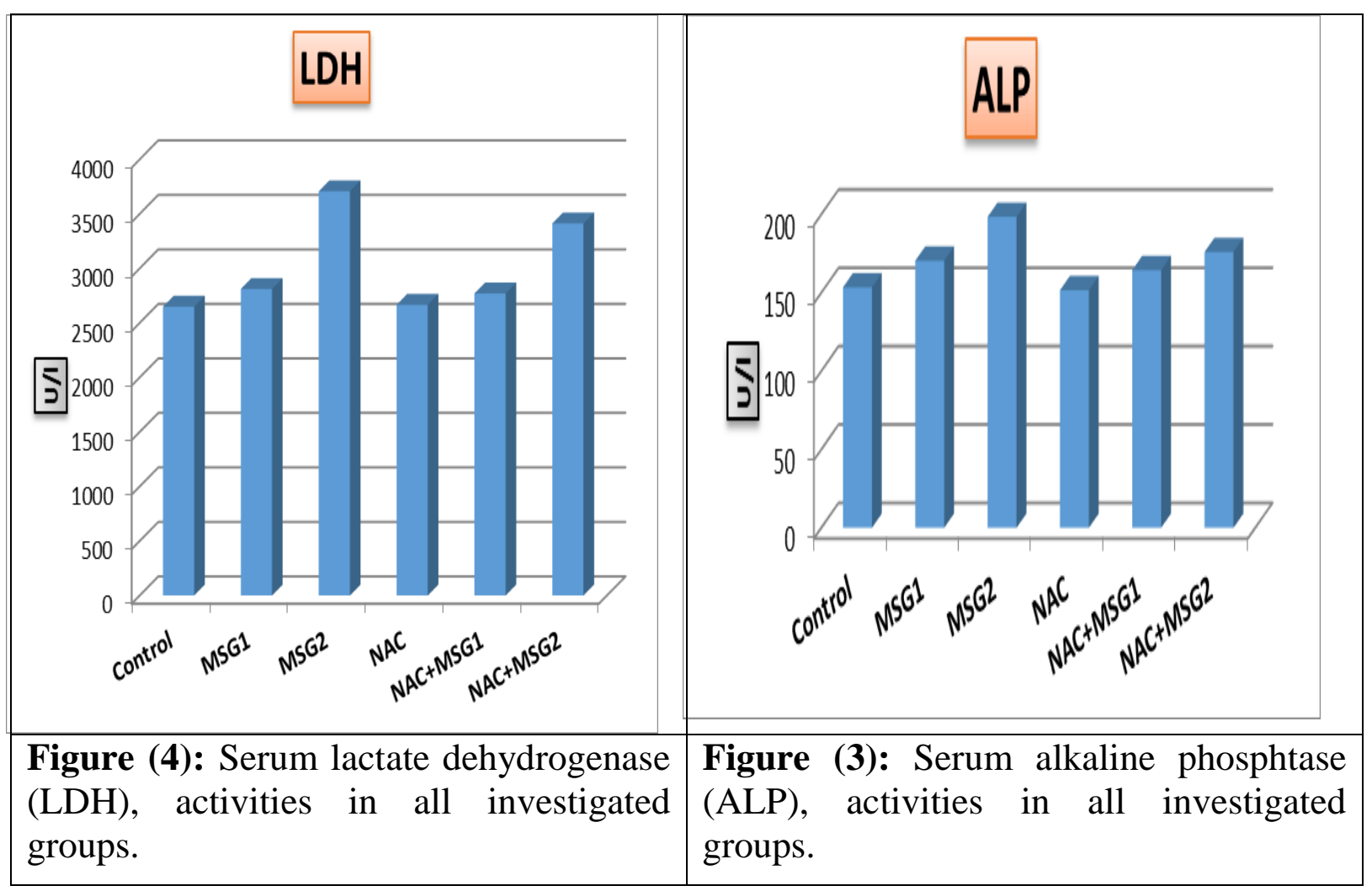




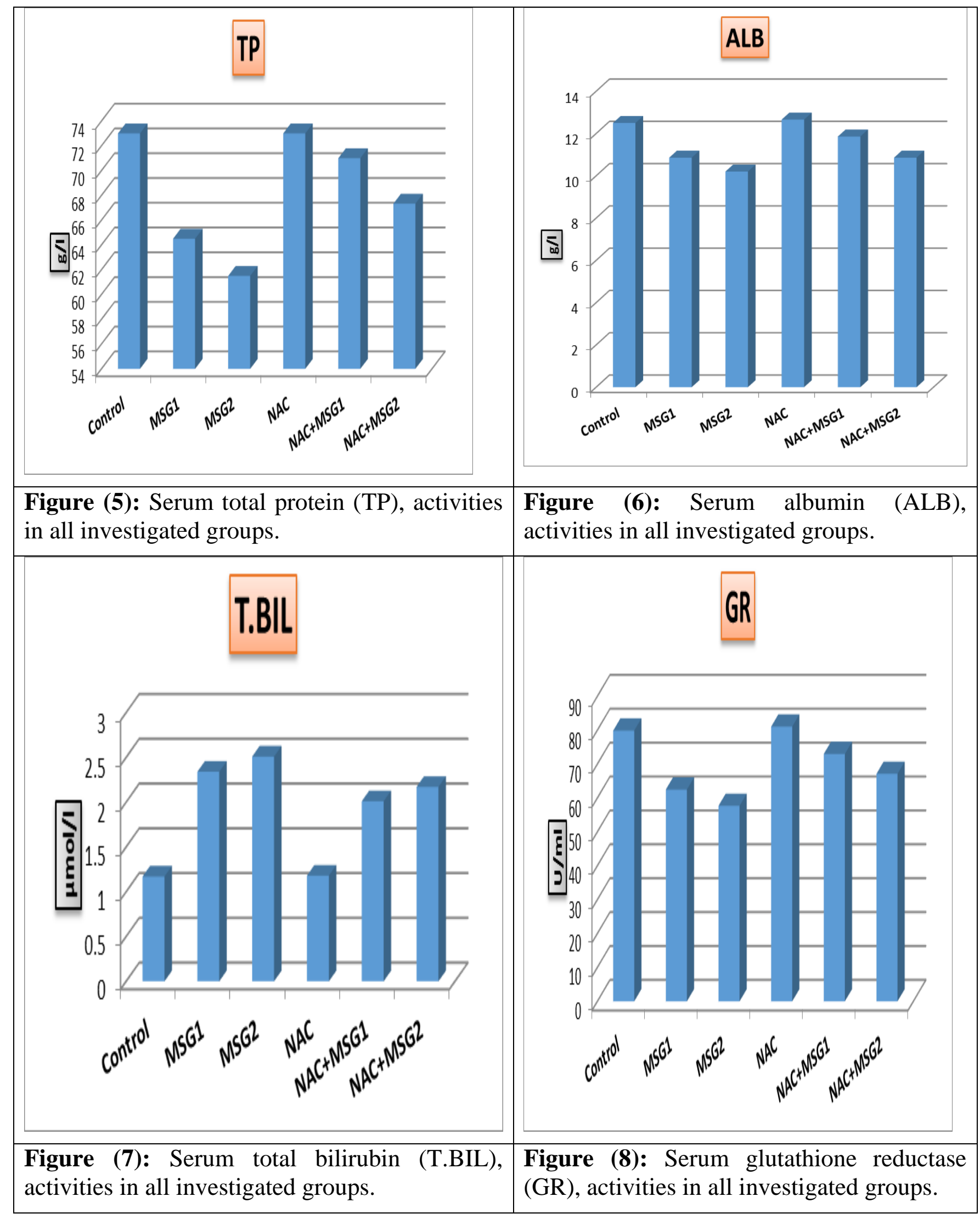




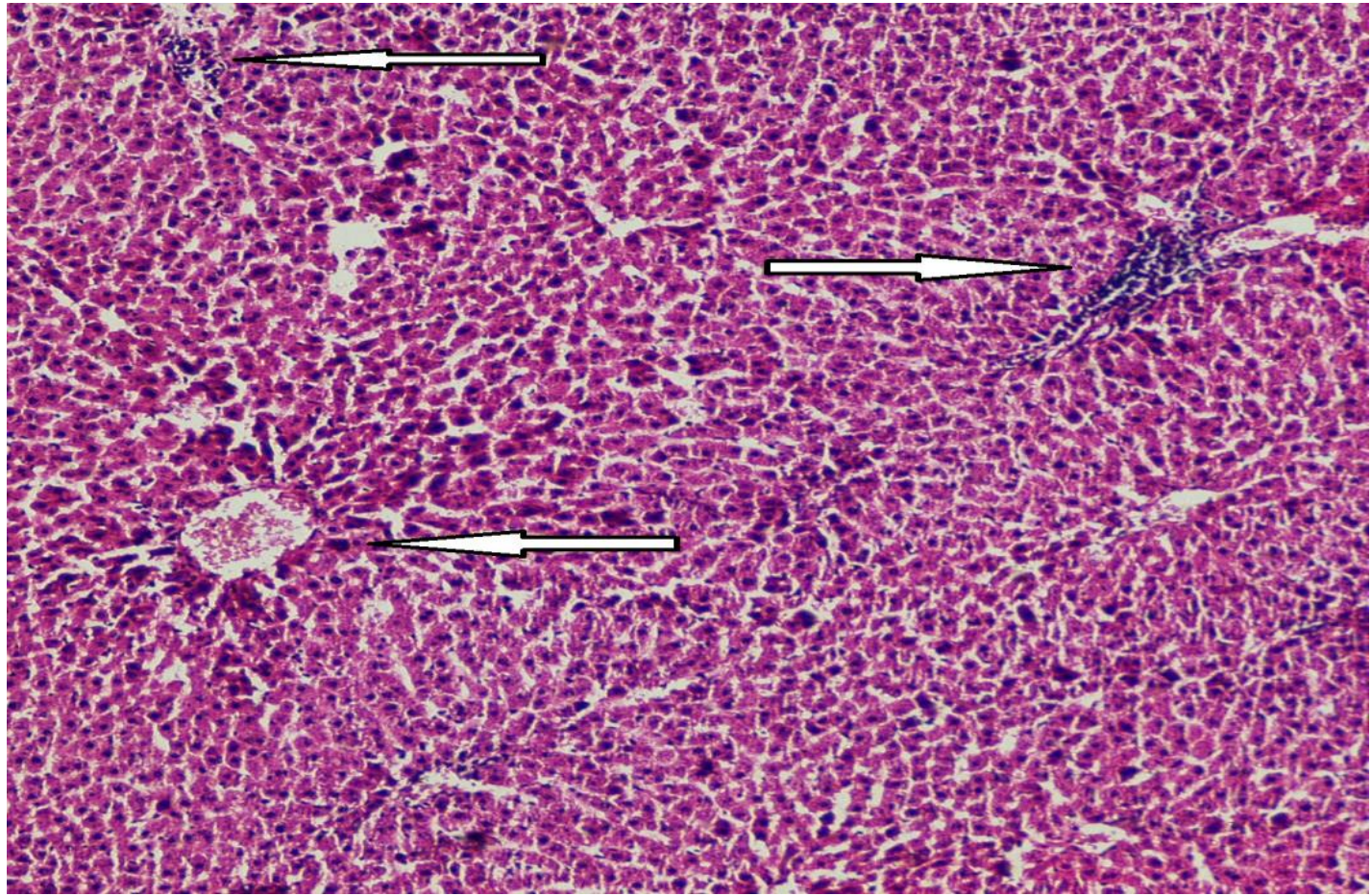

Figure (9): photomicrograph of group (1) rats showing normal liver (H\&E) x 200. Irregular interconnecting sheets radiated outwards from the central vein and constituted the parenchyma of the lobule.

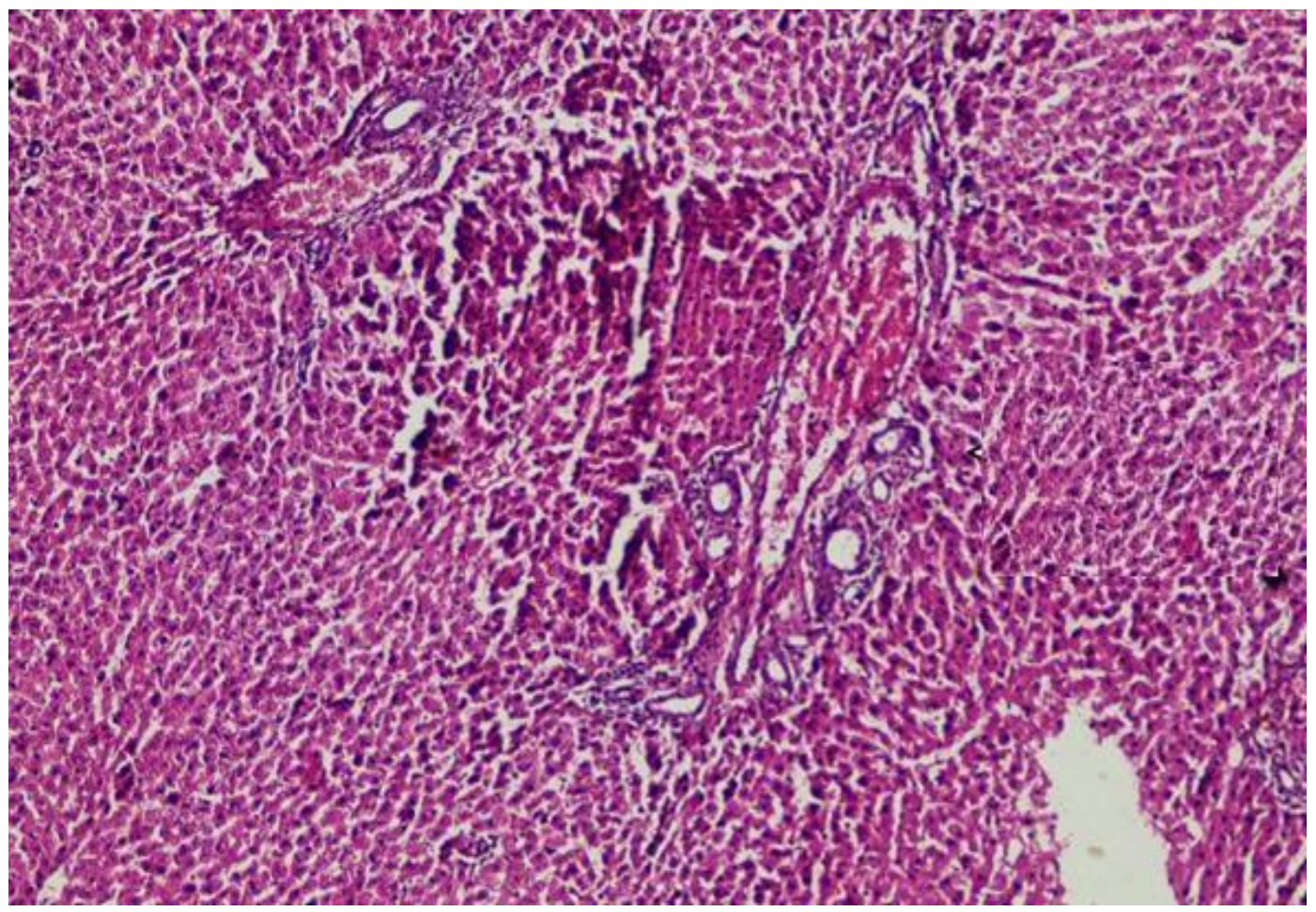

Figure (10): Photomicrograph of liver of group (2) rats shows congested central vein.

Hepatic cells infiltrated with inflammatory cells. Severe portal tract inflammation. Apoptotic bodies (the hepatic cells are swollen with degeneration of the nuclei with prominent nucleoli) (H\&E) x 200. 


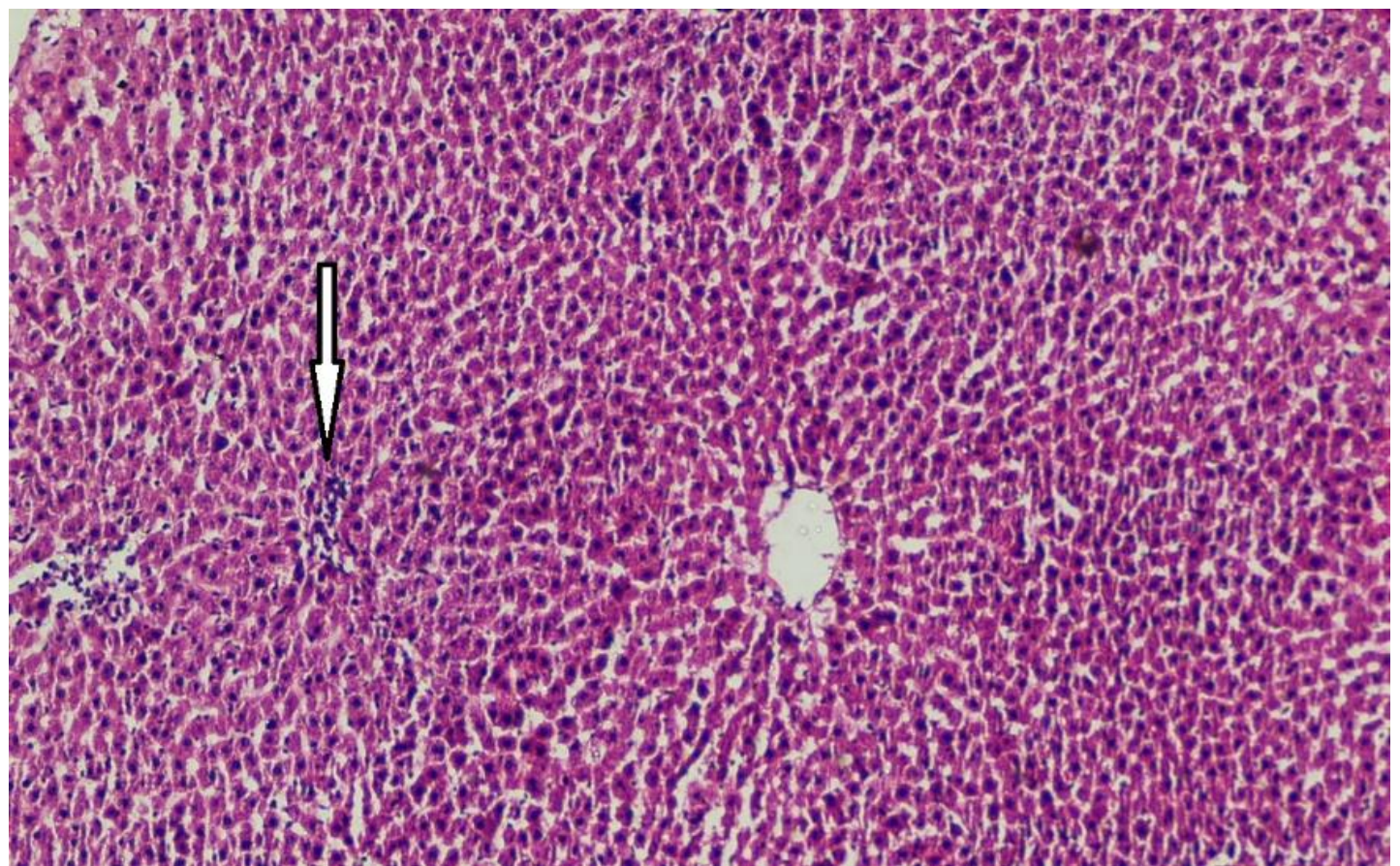

Figure (11): Photomicrograph of liver of group (3) shows necro-inflammatory foci with infiltration of inflammatory cells through the hepatic lobules. The portal tract showed inflammation (portal triaditis).

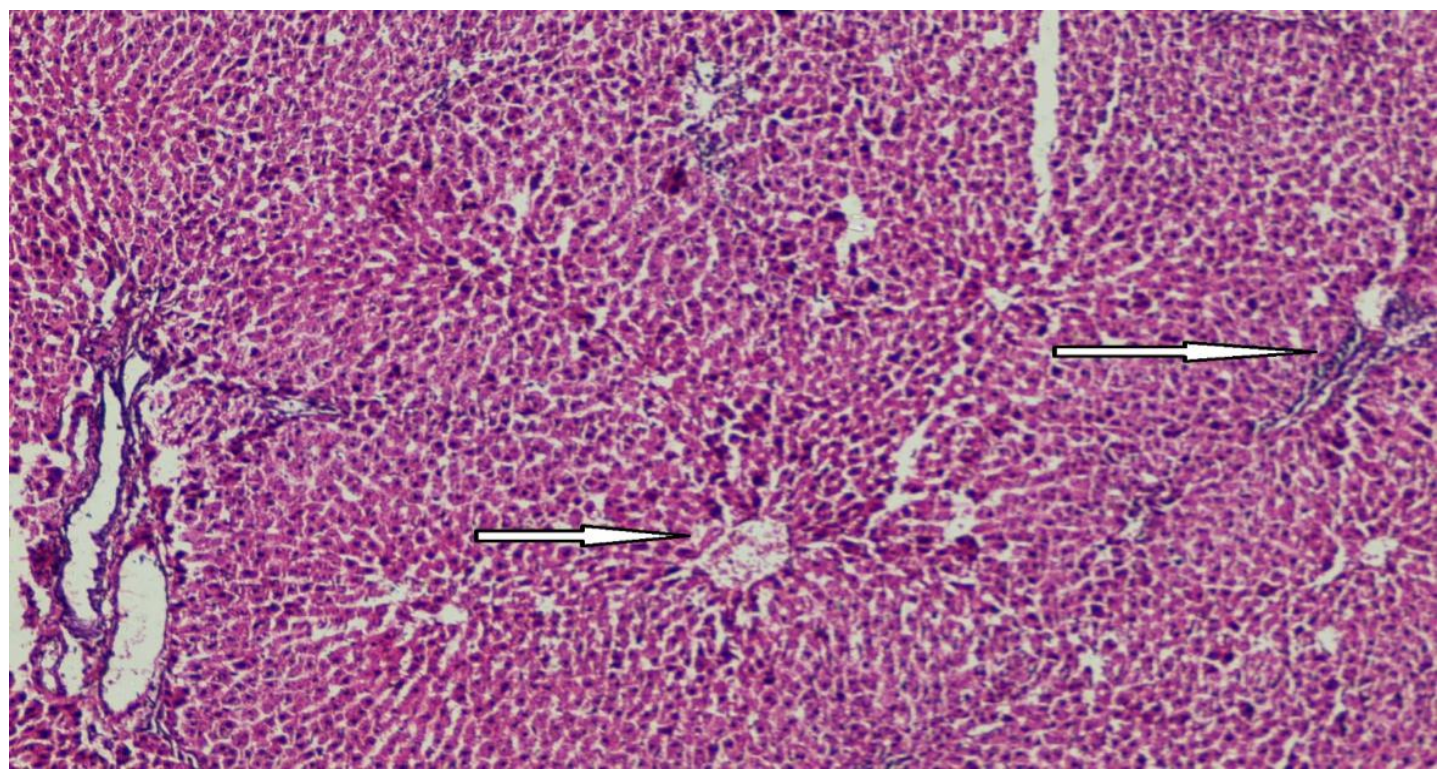

Figure (12): Photomicrograph of liver of group (5) shows mild inflammatory cells infiltration with few apoptotic bodies and absence of central vein congestion. 


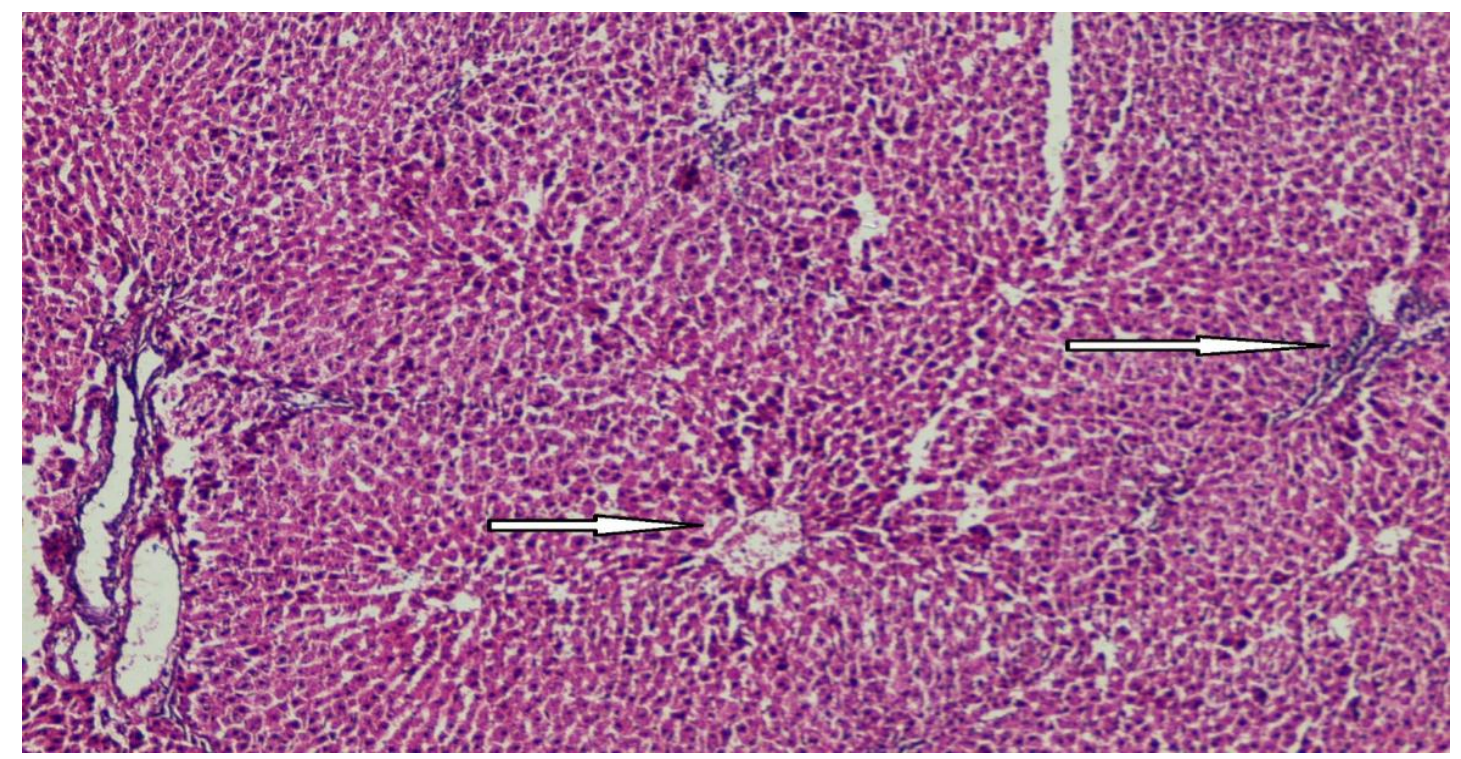

Figure (13): Photomicrograph of liver of group (6) shows infiltration of inflammatory cells through the hepatic lobules and within portal tract, central vein congestion and some apoptotic bodies with absence of necrotic areas.

\section{DISCUSSION}

MSG is widely used as a flavor enhancer in many of the processed foods and drinks (Rundlett and Armstrong, 1994). At the time of discovery, MSG was thought to be safe since it was a natural substance (an amino acid). Recently considerable attention has been focused on its unusual side effects (Reis et al., 2009; Beas-Zarate et al., 2002).

The current study revealed significant elevation of liver enzymes ALT, AST (in the groups 2 and 3) and ALP (in group 3) in comparison with control group. These results indicate that consumption of MSG even at a low concentration may lead to liver cell damage. These findings were in agreement with Hosam et al., (2012) who reported that statistical significant increase of liver enzymes activities values such as ALT, AST and ALP in the group which received MSG alone in comparison with control group. Also, these results seemingly agree with (Farombi and Onyema, 2006 ; Onyema et al. 2006) studies who report that the increase serum ALT in male rats which were fed MSG is probably due to MSG induced oxidative stress in the liver.

The enzyme ALT is localized to cytosol of hepatocytes alone with high specificity and it is increased after hepatic cellular injury (Sherlock, 1997). The ALT enzyme is a sensitive marker of liver damage (Al-Mamary et al., 2002). When its level within limits, it is indicative of hepatocellular damage and that can therefore provide quantitative assessment of the degree of damage sustained by the liver (Aniagu et al., 2004). The metabolism of amino acids and their derivatives occur to a significant extend in the liver (Mayes and Bender, 2003) and essentially involves deamination to produce ammonium ion $\mathrm{NH} 4+$ that could be toxic unless detoxified via urea cycle reactions. The sodium moiety of MSG could dissociate easily to release free glutamate. Thus, the possible NH4+ overload that may occur as a result of an increased level of glutamate following $\mathrm{MSG}$ intake could damage 
the liver, consequently releasing the ALT enzyme that may lead to its observed elevation.

The rise of AST level in the serum can be reflective of probably MSGinduced damage to the liver and other organs with high metabolic activity including the brain, heart and lungs as previously reported by (Egbuonu et al., 2010), since AST enzyme is contrary to ALT enzyme is not a specific marker in organ damage.

Elevation of serum ALP can be an indicator of cholestasis or hepatocellulas damage. Pincus and Abraham, (2006) showed that rise in ALP level results from any disease which will affect hepatocyte secretion because it is represented near the canalicular membrane of the hepatocyte. Cholestasis may result from the blockage of the bile duct or from a disease that impairs bile formation in the liver itself (Stegink et al., 1985). Elevation of ALP occurred only in the third group can be attributed to ongoing hepatocellular toxicity that occur in higher dose of MSG.

Serum LDH (in group 3) and TBIL (in groups 2 and 3) were found to be significantly increased as compared to control group. In contrast, serum ALB and TP were found to be significantly decreased (in groups 2 and 3) when compared to the control group. It can be deduced that serum LDH elevation need higher dose of MSG. The trend of elevated LDH gave an indication of liver cell injury, as hepatic status can be explored by determination of plasma enzymes such as ALT, AST, ALP and LDH (Burtis and Ashwood, 1999). The concentration of proteins, albumin and bilirubin in serum can be used as indicators for the state of the liver and can be used to differentiate between different types of liver damage. The observed reduction in ALB and TP and the increased TBIL levels may be an indication of possible MSG-mediated hepatocellular damage arising from the uptake of MSG and could be reflective of diminished synthetic function of the liver (Naganna, 1991). Elevated TBIL may be a result of cholestasis or hepatic cell injury. These results were partially in accordance to Manal and Nawal, (2012) who observed decrease in ALB level in MSG treated groups. Meanwhile, our results disagree with Manal and Nawal, (2012) regarding serum TBIL and TP, as they observed no significant statistical change in total proteins and significant statistical decrease in serum total bilirubin in MSG treated groups.

High oxidative stress in liver cells can be deduced from the observed significant statistical decreases in serum GR in MSG-fed rats at both doses (in groups 2 and 3) as compared to the control group. MSG is the sodium salt of glutamic acid. Excessive sustained glutamate receptor stimulation with persistent depolarization can produce metabolic and functional exhaustion (Gill, 2000; Mattson, 2008). Some studies have suggested that high concentrations of glutamate induced depletion of cellular antioxidants, such as GSH and ascorbate (Shih et al., 2006; Tojo et al., 2002). Lack of antioxidants easily induces more accumulation of intracellular ROS that elevates the oxidative stress (Tojo et al., 2002). Furthermore, recent data suggest that the excessive level of glutamate caused increase of cellular calcium, ROS generation, and mitochondrial dysfunction (Goldsmith, 2000; Jiang et al., 2005). 
Administration of NAC to MSGtreated rats was found to be effective in improving MSG-induced liver cell damage at both MSG doses. The use of NAC revealed significant reduction in serum level of AST, ALT enzymes and TBIL (in groups 5 and 6) compared to groups 2 and 3 . These findings seem similar to Manal and Nawal, (2012) who reported that administration of V.C and V.E resulted a significant reduction in the serum level of ALT enzyme at both MSG doses. In contrast, Manal and Nawal, (2012) reported that serum total bilirubin was found to be significantly increased in the serum after administration of vitamin C and vitamin E with MSG. Serum ALP levels showed no significant change (in groups 5 and 6 when compared to groups 2 and 3) which may indicate that the hepatic capacity of the liver is grossly affected by MSG. Also, it may indicate that NAC cannot affect cholestasis.

Serum LDH levels were found to be significantly reduced after using NAC to MSG-fed rats (in group 6 compared to group 3). On the other hand, administration of NAC was effective in improving the synthetic function of the liver especially with lower dose of MSG as the results revealed significant statistical increases in serum ALB, TP (in group 5 only as compared to group 2). These results were in accordance to Manal and Nawal, (2012) who observed that addition of V.E and V.C resulted in a significant improvement in the serum total protein levels of lower MSG dosed rats $(0.6 \mathrm{mg} / \mathrm{g}$ b.wt $)$. Both vitamins have the ability to prevent oxidative stress which affects liver the main site for protein synthesis in the body. Albumin concentration increased in the serum of MSG administrated by addition of V.C and V.E dosed rats.

In addition, NAC can effectively reduce the oxidative stress of liver cells as observed from elevation of GR enzyme (in groups 5 and 6 when compared to groups 2 and 3). This appears to suggest an attempt by NAC to counteract or antagonize the probable liver cells damage. So, NAC has an ameliorating effect on MSGinduced hepatotoxicity. To our knowledge, the protective effects of NAC against MSG-mediated hepatotoxicity have not been reported up till now. Thus, the present study has demonstrated for the first time that NAC can be used in protection of the liver from MSG induced toxicity.

Our results can be comparable to Reham and Mohammad, 2014 who revealed that administration of vit. E or selenium as anti-oxidant to MSGtreated groups declined lipid peroxidation. Young and Woodside, (2001) reported that Vitamin $\mathrm{C}$ is an antioxidant which removes free radicals products in the body and shows the ability to scavenge superoxide, hydrogen peroxide, and hydroxyl radicals. Generation of reactive oxygen species (ROS) as result of oxidative stress of MSG toxic effect were depressed by antioxidant effect of vitamin $\mathrm{C}$ and this consistent with (Oscar et al., 2006).

The findings of our study can be explained according to (Farombi and Onyema, 2006) that all antioxidants reduce MSG-increase in serum ALT and AST. Antioxidants have been reported to play a significant role in the protection against lipid peroxidation. Vitamin $\mathrm{E}$ is antioxidants that are thought to have a protective effect by either reducing or preventing oxidative 
damage. Lipid soluble vit E prevents lipid peroxidation chain reactions in cellular membranes by interfering with the propagation of lipid radicals (Rinne et al., 2000). It is well known as nonenzymatic antioxidant (Al-Attar, 2011; Uzun et al., 2009).Vitamin $E$ inhibits peroxidation of membrane lipids by scavenging lipid peroxyl radicals (EIDemerdash et al., 2004; Uzunhisarcikli and Kalender, 2011), and it also inhibits oxidative damage in several tissues by heavy metals and pesticides in experimental animals (EIDemerdash et al., 2004; Acharya et al., 2008).

$\mathrm{N}$-acetylcysteine NAC, an acetylated sulfur-containing amino acid, is a lipid soluble antioxidant that can permeate cell membranes. It can act through several mechanisms against cellular degeneration. It is currently used in respiratory diseases, and as a treatment for acetaminophen hepatotoxicity, because NAC has beneficial effects in conditions characterized by decreased GSH or oxidative stress in those diseases. It acts as a precursor of GSH synthesis, and has potential benefits as an antiapoptotic and anti-inflammatory agent (Cooper and Kristal, 1997; Seaton et al., 1997; Yang et al., 2012). It stimulates cytosolic enzyme activities involved in the glutathione cycle, such as glutathione reductase, which enhances the rate of glutathione regeneration. Glutathione is a principal thiolic compound, play a key role in cellular homeostasis since its loss is accompanied by cell death caused by oxidative stress (Reed and Fariss, 1984). Also, NAC also acts by direct reaction between its reducing thiol group and ROS protecting against oxidative damage in vitro and in vivo

\section{(Aruoma et al., 1989).}

Wong et al., (2003) investigated the protective effect of NAC against carbontetrachloride (CCl4) and trichloroethylene-induced

hepatotoxicity in rats. Rats administered with higher dose of NAC caused significant reduction in SGPT and SGOT levels. They concluded that NAC effectively protects against $\mathrm{CCl} 4$ and trichloroethylene-induced hepatotoxicity in rats. NAC pretreatment partially decreased the covalent binding of $\mathrm{CCl} 4$-reactive metabolites at 1 st and 3rd hour of poisoning. NAC also diminished partially the CCl4-induced increase in lipid peroxidation. The early protective effects of NAC might be attributable to its prior conversion to cysteine and GSH (Menor et al., 2003).

Azathioprine (AZA) decreased the viability of cultured hepatocytes, depleted intracellular GSH, reduced metabolic activity, mitochondrial swelling, increased oxygen consumption of intact mitochondria and LDH release. NAC reversed AZAinduced hepatotoxicity in humans by increasing cytosolic GSH (Valles et al., 1994).

As regards histopathological results, the present study showed congested central vein, apoptotic bodies and inflammatory cells infiltration through the hepatic lobules and within portal tract in group 2 rats. These findings indicate liver cell injury. Necro-inflammatory foci were revealed within the hepatic lobule in group 3 rats. Necrosis can be attributed to severe liver cell injury and degeneration. Administration of NAC in Group 5 rats was associated with mild inflammatory cells infiltration 
(when compared to group 2) with few apoptotic bodies and absence of central vein congestion. In group 6 rats, administration of NAC to $1.6 \mathrm{mg} / \mathrm{gm}$ MSG elicited infiltration of inflammatory cells through the hepatic lobules and within portal tract, central vein congestion and some apoptotic bodies with absence of necrotic areas (when compared to group 3). Improvement of MSG-induced hepatic histopathological changes was observed in rats after adding NAC to MSG-fed groups. This means that NAC has anti-oxidant effect and protective role against liver cell injury. Sakr et al., (2003) reported that histopathological changes due to toxic effect of MSG on the liver were in the form of distortion of hepatocytes and dilatation of central vein of the liver. Hossam et al., 2012 revealed that MSG caused foci of degeneration in the form of pyknosis of hepatocytes nuclei and fibrosis. Egbuonu et al., (2009) indicated that MSG induced hepatic necrosis and apoptosis, biliary proliferation, peribiliary fibrosis and degeneration of hepatocytes. Hazar et al., (2008) referred that oxidative stress which is responsible for the development of hepatic fibrosis and degeneration.

\section{CONCLUSION}

Administration of MSG significantly increased the levels of AST, ALT, LDH and bilirubin, the markers of hepatotoxicity, and decreased the levels of albumin and total protein. MSG may be hepatotoxic at a low dose, hence should be avoided during the treatment of liver disorders. Supplementation with NAC decreased the markers of hepatotoxicity and exerted significant protection against MSG-induced toxicity by its ability to decrease the lipid peroxidation and thus oxidative stress through its free radicalscavenging activity, which improved the levels of antioxidant defense system. NAC at $200 \mathrm{mg} / \mathrm{kg}$ improved the hepatic histopathological damages induced by MSG. This study revealed the hepatoprotective potential of NAC against MSG-induced liver damage.

\section{REFERENCES}

Acharya U.R., Mishra M., Patro J., Panda M.K. (2008): Effect of vitamins $\mathrm{C}$ and $\mathrm{E}$ on spermatogenesis in mice exposed to cadmium Reprod. Toxicol., 25, 84-88

Al-Attar A.M. (2011): Antioxidant effect of vitamin $E$ treatment on some heavy metals-induced renal and testicular injuries in male mice Saudi J. Biol. Sci., 18: 63-72

Al-Mamary M., Al-Habori M., AlAghbari A.M. and Baker M.M. (2002): Investigation into the toxicological effects of Catha edulis leaves: a short-term study in animals. Phytoether Res. 16: 127132.

Aniagu, S.O., Nwinyi F.C., Akumka D.D., et al., (2004): Toxicity studies in Rats fed nature cure bitters. Afr. J. Biotechnol., 4(1): 72-78.

Aruoma O.I., Halliwell B., Hoey B.M., Butler J. (1989) : The antioxidant action of Nacetylcysteine: its reaction with hydrogen peroxide, hydroxyl radical, superoxide, and hypochlorous acid Free Rad. Biol. Med., 6, pp. 593-597.

Beas-Zarate C., Perez-Vega M.I. and Gonzalez- Burgos I., (2002): Neonatal exposure to monosodium L-glutamate induce 
loss of neurons and cytoarchitectural alternations in hippocampal CA1 pyramidal neurons of adult rats. Brain Res., 952: 275-281.

Berkes E.A. and Wossner K.M. , (2003): Monosodium glutamate. In Food allergy: Adverse reactions to food and food additives, Eds. Metcafe, D.D. H.A. Sampson and R.A. Simon. pp: 343350.

Beyreuther K., Biesalski H.K., Fernstrom JD (2007): "Consensus meeting: monosodium glutamate an update". Eur. J. Clin. Nutr., 61 (3): 304-13.

Burtis C. and Ashwood E. (1999): "Tietz Textbook of Clinical Chemistry," W. B. Saunders Company, London.

Carlberg I. and Mannervik B. (1985): Glutathione reductase, Methods Enzymol., vol. 113: 484490.

Cooper A.J. and Kristal B.S. (1997): Multiple roles of glutathione in the central nervous system. Biol. Chem. 378, 793-802.

Cortese B.M. and Phan L.K. (2005): The Role of Glutamate in Anxiety and Related Disorders. CNS Spectr., 10(10): 820-830.

Egbuonu A.C., Obidoa O., Ezeokonkwo C.A., et al., (2009): Hepatotoxic effects of low dose oral administration of monosodium glutamate in male albino rats. African Journal of Biotechnology 8 (13): 3031-3035.

Egbuonu A.C., Ezeokonkw C.A, Ejikeme P.M., et al., (2010): Some Bbiochemical effects of subacute oral administration of Larginine on monosodium glutamate-fed wistar albino rat 2 : serum alkaline phosphatase, total acid phosphatase and aspartateaminotransferase activityies .Asian J. Biochem., 5: 89-95

El-Demerdash F.M., Yousef M.I., Kedwany F.S., and Baghdadi H.H. (2004): Cadmium induced changes in lipid peroxidation, blood hematology, biochemical parameters and semen quality of male rats: protective role of vitamin $\mathrm{E}$ and $\beta$-carotene Food Chem. Toxicol., 42: 1563-1571

Farombi E.O. and Onyema O.O. (2006): Monosodium glutamateinduced oxidative damage and genotoxicity in the rat: modulatory role of vitamin $\mathrm{C}$, vitamin $\mathrm{E}$ and guercetin. Human Experimental Toxicol. 125: 251-259.

Freeman M. (2006): "Reconsidering the effects of monosodium glutamate: a literature review". J Am. Acad. Nurse Pract. 18 (10): 482-6.

Furst P. and Stehle P. (2004): What are the essential elements needed for the determination of amino acid requirements in humans? J. Nutr. 34: $1558-1565$

Geha R., Beiser A., Ren C. et al., (1998): Multicenter multiphase double blind placebo controlled study to evaluate alleged reactions to monosodium glutamate (MSG). J. Allergy Clin. Immunol. 101: 243

Gill S.S. (2000): Potential target sites in peripheral tissues for excitatory neurotransmission and excitotoxicity Toxicol. Pathol., 28 : 277-284

Goldsmith P.C. (2000): Neuroglial responses to elevated glutamate in the medial basal hypothalamus of the infant mouse J. Nutr., 130 : 
1032-1038

Hazar Y., Nayira A., Hala A.A. et al., (2008): Hepatoprotective Effect of $\mathrm{N}$-acetyl Cysteine and/or âCarotene on Monosodium Glutamate-Induced Toxicity in Rats . Research Journal of Medicine and Medical Sciences, 3(2): 206-215.

Hossam S. Ali, Amal A. El-Gohary, Fatma G. Metwally, et al., (2012): Mono Sodium Glutamate-induced Damage in Rabbit Retina: Electroretinographic and Histologic Studies Global Journal of Pharmacology, 6 (3): 148-159

Jiang S.X., Lertvorachon J., Hou S.T., et al., (2005): Chlortetracycline and demeclocycline inhibit calpains and protect mouse neurons against glutamate toxicity and cerebral ischemia J. Biol. Chem., 280: 33811-33818

Manal Said Tawfik and Nawal AlBadr (2012): Adverse Effects of Monosodium Glutamate on Liver and Kidney Functions in Adult Rats and Potential Protective Effect of Vitamins $C$ and $E$ Food and Nutrition Sciences, , 3, 651-659

Manivasagan T. and Subramanian P. (2004): "Monosodium Glutamate Affects the Temporal Characteristics of Biochemical Variables in Wistar Rats," Polish Journal of Pharmacology, Vol. 56, No. 1, , pp. 79-84.

Mattson M.P. (2008): Glutamate and neurotrophic factors in neuronal plasticity and disease Ann. NY Acad. Sci., 1144, pp. 97-102

Mayes P.A. and Bender D.A. (2003): The citric acid cycle. The catabolism of Acetyl-CoA. In
Harper's illustrated Biochemistry $26^{\text {th }}$ edn.. Murray R.K., D.K. Granner, P.A Mayes and V.W Rodwell (eds). Lange Mmedical Books Mc/Grawhill companies New Yourk

Menor C., Cara C.J., FernandezMoreno M.D., et al. (2003): Protective role and molecular basis of N-acetyl-L-cysteine usage in azathioprine-induced rat hepatocyte necrosis. Gastroenterology.;124: 723.

Moore K.L. (1999): Congenital Malformations due to Environmental Factors. 2nd Edt., Developing Humans W.B Saunders Co. Ltd. Philadelphia, pp:173-183.

Moreno G., Perello M., Gaillardandand R.C., et al., (2005): Orexina stimulates hypothalamic- pituitvadrenal (HPA) axis function, but not food intake in the absence of full hypothalamic NPY- ergic activity. Endocrine, 26: 99-106.

Mozes S. and Sefcikova $Z$. (2000): Obesity and changes of alkaline phosphatase activity the small intestine of 40 and 80-day old rats subjected to early postnatal overfeeding of monosodium glutamate. Physiol Res., 2: 177186.

Naganna B. (1989): "Plasma Proteins," In: G. P. Talwar, L. M. Srivastava and K. D. Moudgil, Eds., Textbook of Bio- chemistry and Human Biology, 2nd Edition, Prentice Hall of India Private Ltd., New-Delhi, , pp. 59-61.

Obaseiki-Ebor E.E., McGhee E.M., Shankee D.M. (2003). Improved detection of the genotoxic and mutagenic potentials of a food 
condiment A-One (monosodium glutamate). Presented at the Fourth International Conference of the pan-African Environmental Mutagen Society (PAEMS) in Dar El Diafa- Ain Shams University, Cairo Egypt. 2-4th March: p. 63.

Onyema O.O., Farombi E.O., Emerole G. O., et al., (2006): "Effect of Vitamin E on Monosodium Glutamate Induced Hepatoxicity and Oxidative Stress in Rats," Indian Journal of Biochemistry \& Bio- physics, 43(1): 20-24.

Ortiz G.G , Bitzer-Quintero O.K., Beas Zárate C., et al., ( 2006 ): Monosodium glutamate induced damage in liver and kidney: a morphological and biochemical approach Biomedicine \& Pharmacotherapy. 60: 86-91

Oscar O.W., Ebenezer O.F., Godwin O.E., et al., (2006): Effect of vitamine $\mathrm{E}$ on monosodium glutamate induced hepatotoxicity and oxidative stress in rats. Indian Journal of Biophysics, 43 :20-24.

Oyetunji T. K. (2013): Assessment of the effects of monosodium glutamate on some biochemical and hematological parameters in adult wistar rats American Journal of BioScience; 1(1): 11-15

Pavlovic V., Pavlovic D., Kocic D., et al (2007): Effect of monosodium glutamate on oxidative stress and apoptosis in rat thymus. J. Mol. CellBiochem., 303: 161-166.

Pincus M.R. and Abraham N.Z. (2006): Interpreting laboratory results. In: McPherson RA, Pincus MR, eds. Henry's Clinical Diagnosis and Management by Laboratory Methods. 21st ed. Philadelphia, Saunders Elsevier; chap 8 .

Reed D.J. and Fariss M.W. (1984): Glutathione depletion and susceptibility Pharmacol. Rev., 36, pp. 255-335

Reham Z. Hamza and Mohammad S. AL-Harbi. (2014): Monosodium glutamate induced testicular toxicity and the possible ameliorative role of vitamin $\mathrm{E}$ or selenium in male rats $1: 1037-$ 1045

Reis H.J., Guatimosim C., Paquet M., et al., (2009): Neurotransmitters in the central nervous system \& their implication in learning and memory processes. Curr. Med. Chem. 16: 796-840.

Rinne T., Mutschler E., WimmerGreinecker G., et al., (2000): Vitamins $\mathrm{C}$ and $\mathrm{E}$ protect isolated cardiomyocytes against oxidative damage Int. J. Cardiol., 75: 275281

Rundlett K.L. and Armstrong D.W. (1994): Evaluation of free Dglutamate in processed foods. Chirality, 6: 277-282

Sakr S., Okdah A., El-Abed F. (2003): Gibberellin A3 Induced Histological and Histochemical Alterations in the liver of Albino Rats,Sience Asia 29 : 327-331.

Samuels A. (1999): "The Toxicity/Safety of MSG: A Study in Suppression of Information," Accountability in Research, 6 (4): 259-310.

Seaton T.A., Cooper J.M., Schapira, A.H. (1997): Free radical scavengers protect dopaminergic cell lines from apoptosis induced by complex 1 inhibitors. Brain Res.777, 110-118.

Sherlock S. (1997): Assessment of liver function Disease of liver and 
biliary system: Sheila Sherlock, 10th ed., London; Blackwell science ltd; 17-32.

Shih A.Y., Erb H., Sun X., et al., (2006): Cystine/glutamate exchange modulates glutathione supply for neuroprotection from oxidative stress and cell proliferation J. Neurosci., 26, pp. 10514-10523

Stegink L.D., Filer J.r., Baker G.L. (1985): Plasma glutamate concentrations in adult subjects ingesting monosodium L-glutamate in consomme. Am. J. Clin. Nutr. 42: 220-225.

Tojo A., Onozato M.L., Kobayashi N., et al., (2002): Angiotensin II and oxidative stress in Dahl saltsensitive rat with heart failure Hypertension, 40: 834-839

Uzun F.G., Kalender S., Durak D., et al., (2009): Malathion-induced testicular toxicity in male rats and the protective effect of vitamins $C$ and E Food Chem. Toxicol., 47: 1903-1908

Uzunhisarcikli M. and Kalender Y.
(2011): Protective effects of vitamins $\mathrm{C}$ and $\mathrm{E}$ nst hepatotoxicity induced by methyl parathion in rats Ecotoxicol. Environ. Saf. 74: 2112-2118

Valles E.G., de Castro C.R., Castro J.A. (1994): N-Acetyl cysteine is an early but also a late preventive agent against carbon tetrachlorideinduced liver necrosis. Toxicol Lett. 71: 87-95.

Wong C.K., Ooi V.E., Wong C.K. (2003): Protective effects of Nacetylcysteine against carbon tetrachloride and trichloroethylene induced poisoning in rats. Environ Toxicol Pharmacol.14:109-116.

Yang L., Tan P., Zhou W., et al., (2012): $\mathrm{N}$-acetylcysteine protects against hypoxia mimetc-induced autophagy by targeting the HIF- $1 \alpha$ pathway in retinal ganglion cell. Cell Mol. Neurobiol. 32: 12751285.

Young IS and Woodside JV (2001): Antioxidants in health and disease. J. Clin. Pathol. 54(3):176-86. 


\section{التسمم الكباي الناجم عن الجلوتامات أحادية الصوبي فيوم في الفئران و الدور المحتمل ل

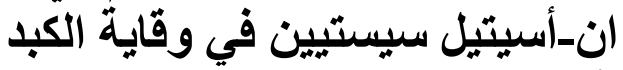

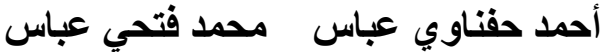

قسم الطب الثرعي والسموم الاكلينيكية ، كلية الطب - جامعة المنيا

الجلوتامات أحادية الصوديوم (MSG) يتم تسويقها عادة كمحسن نكهة وتستخدم كاضافة غذائية. وقد أجريت هذه الدراسة لبحث تأثثرها على وظائف الكبد خلال فترة أسبو عين في الفئران ولدراسة تأثثير ان- أسيتيل

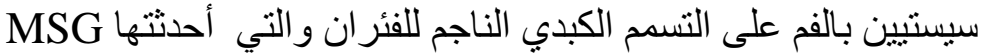

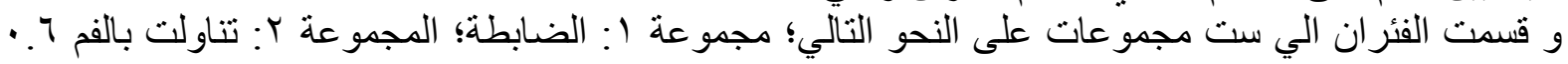

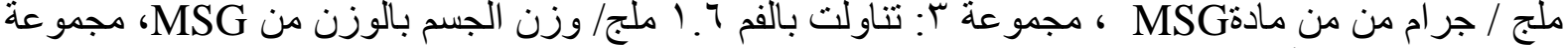

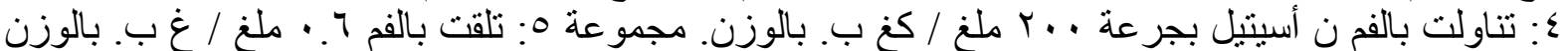

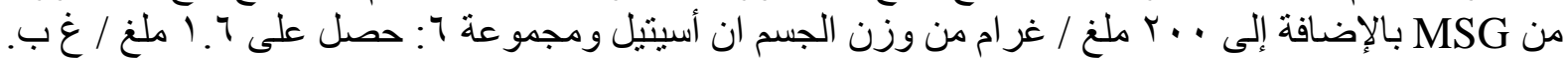

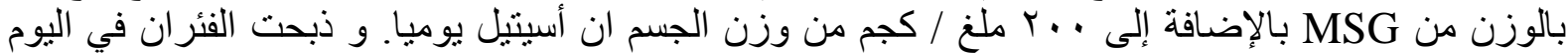

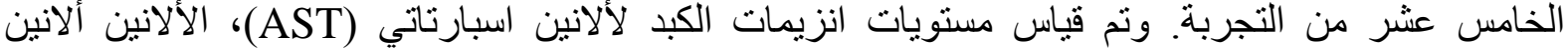

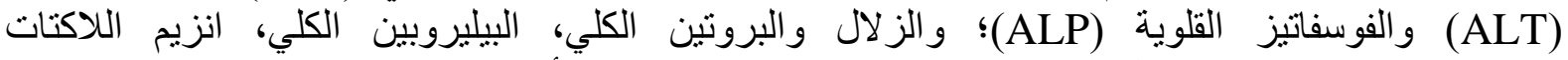

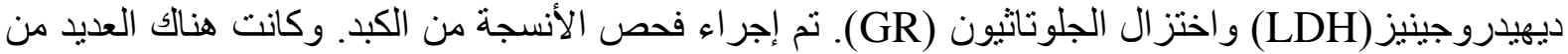

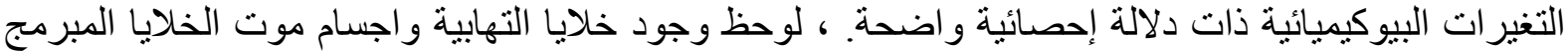

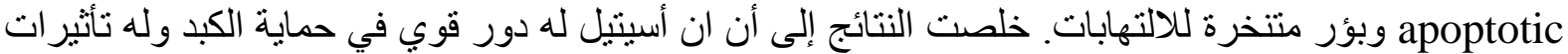

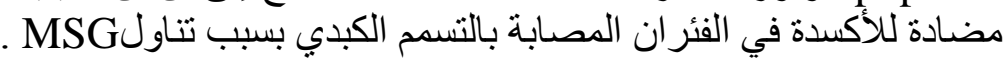

